\title{
CONSTRAINTS ON COMPOSITION OF POSSIBLE DIAMOND- BEARING LITHOSPHERE AS SAMPLED BY THE VICTOR KIMBERLITE
}

\author{
Smit $\mathrm{KV}^{1 *}$, Stachel $\mathrm{T}^{\mathbf{1}}$ and Seller, $\mathbf{M}^{\mathbf{2}}$ \\ ${ }^{1}$ Department of Earth and Atmospheric Sciences, University of Alberta, Edmonton, Canada ${ }^{2}$ De Beers Canada, Toronto, Canada \\ *kvsmit@ualberta.ca
}

The Jurassic Attawapiskat kimberlites, emplaced into the $\sim 3 \mathrm{Ga}$ North Caribou Superterrane of the central Superior craton, sampled diamond-bearing sub-continental lithospheric mantle (SCLM) subsequent to a major thermal event, the $1.1 \mathrm{Ga}$ Midcontinent Rift on the southern craton margin (e.g. White, 1972; van Schmus and Hinze, 1985; Kong et al., 1999; Heaman and Kjarsgaard, 2000). Previous studies have shown that whereas the nearby Kyle Lake kimberlites $(1.1 \mathrm{Ga})$ sampled SCLM containing abundant harzburgite, these are rare at the Attawapiskat kimberlites ( 180 Ma) (e.g. Sage, 1996; Sage, 2000; Armstrong et al., 2004; Scully et al., 2004). This may be due to refertilisation of the SCLM by melts/fluids associated with the Midcontinent Rift.

We aim to assess the diamond-stable regions in the SCLM beneath Attawapiskat and any impact the Midcontinent Rift may have had on these diamond-bearing lithologies. We further aim to determine the different styles of metasomatism that occurred in the SCLM; as melt metasomatism has previously been shown to be detrimental to diamond preservation (e.g. McCammon et al., 2001), its possible occurrence may constrain whether pre-rift diamonds may have survived beneath this region.

Samples for this study include eclogite/pyroxenite xenoliths and mixed parageneses mineral concentrate from the Victor Mine at Attawapiskat. We analysed a suite of 30 xenoliths 17 bimineralic eclogite xenoliths have omphacitic clinopyroxene and garnet with $6-18 \mathrm{wt} \% \mathrm{MgO}$. Thirteen pyroxenite xenoliths -5 of which are orthopyroxene bearing - have diopsidic clinopyroxene and garnet with 15 $21 \mathrm{wt} \% \mathrm{MgO}$.

Pressures and temperatures of last equilibration could be calculated iteratively for the 5 orthopyroxene-bearing samples, with $\mathrm{T}$ ranging between $730{ }^{\circ} \mathrm{C}$ and $830{ }^{\circ} \mathrm{C}(\mathrm{Ca}-\mathrm{in}-$ Opx; Brey et al., 1990) and $\mathrm{P}$ between $2.3 \mathrm{GPa}$ and $3.4 \mathrm{GPa}$
(Al exchange between Grt-Opx; Nickel and Green, 1985). The bimineralic eclogites and pyroxenites yield temperatures of last equilibration between $790{ }^{\circ} \mathrm{C}$ and 990 ${ }^{\circ} \mathrm{C}$ (calculated at $5 \mathrm{GPa}$; Krogh-Ravna, 2000). Based on $\mathrm{Cr}$ diopside from heavy media concentrate, we employed the single crystal geothermobarometer of Nimis and Taylor (2000) to derive a Jurassic model geotherm equivalent to $\sim 36$ to $38 \mathrm{~mW} / \mathrm{m}^{2}$ surface heat flow. Projecting the thermometric data for eclogites onto this palaeogeotherm places the samples in the graphite stability field.

$\mathrm{Na}_{2} \mathrm{O}$ in garnet and $\mathrm{K}_{2} \mathrm{O}$ in clinopyroxene in the majority of eclogite xenoliths are low $(<0.09 \mathrm{wt} \%$ and $<0.08 \mathrm{wt} \%$, respectively), which is usually taken as an indication that such eclogites are not derived from high pressures in the diamond stability field (McCandless and Gurney, 1989). Only one of the 17 eclogite xenoliths has garnet with elevated $\mathrm{Na}$ contents $\left(\mathrm{Na}_{2} \mathrm{O}=0.1 \mathrm{wt} \%\right)$. However, five of the 13 pyroxenite xenoliths and $26 \%$ of the high $\mathrm{Ca}-$ eclogitic (G3) and low Ca-eclogitic/pyroxenitic (G4)

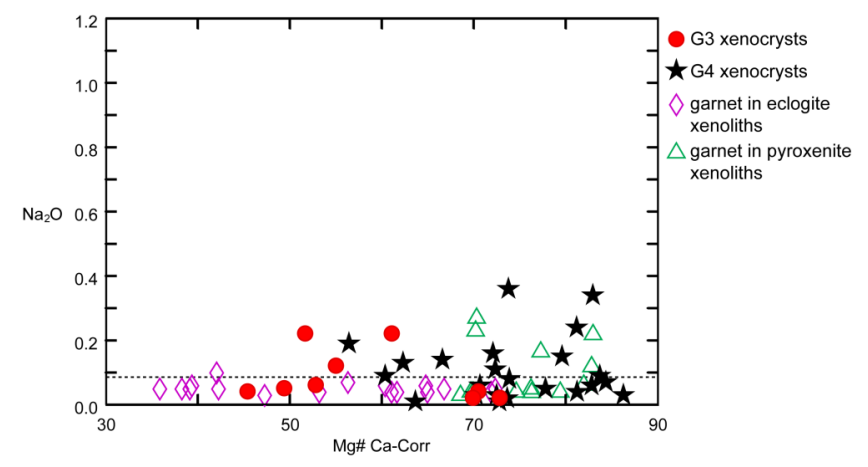

Figure $1 . \mathrm{Na}_{2} \mathrm{O}$ versus $\mathrm{Mg} \#_{\text {Ca-corr }}$ for $\mathrm{G} 3$ (high-Ca eclogitic) and G4 (low$\mathrm{Ca}$ eclogitic to pyroxenitic) xenocrysts picked from mineral concentrate and garnet from eclogite and pyroxenite xenoliths. $\mathrm{Mg} \#_{\text {Ca-corr }}=\mathrm{Mg} \#+2 \mathrm{Ca}$ ( $\mathrm{Ca}$ as cations calculated on a basis of 24 oxygens), valid within the temperature and compositional limits outlined by Stachel et al. (2003). $\mathrm{Na}_{2} \mathrm{O}$ content of $0.09 \mathrm{wt} \%$ is indicated with a dashed line (McCandless and Gurney, 1989). 


\section{$10^{\text {th }}$ International Kimberlite Conference, Bangalore - 2012}
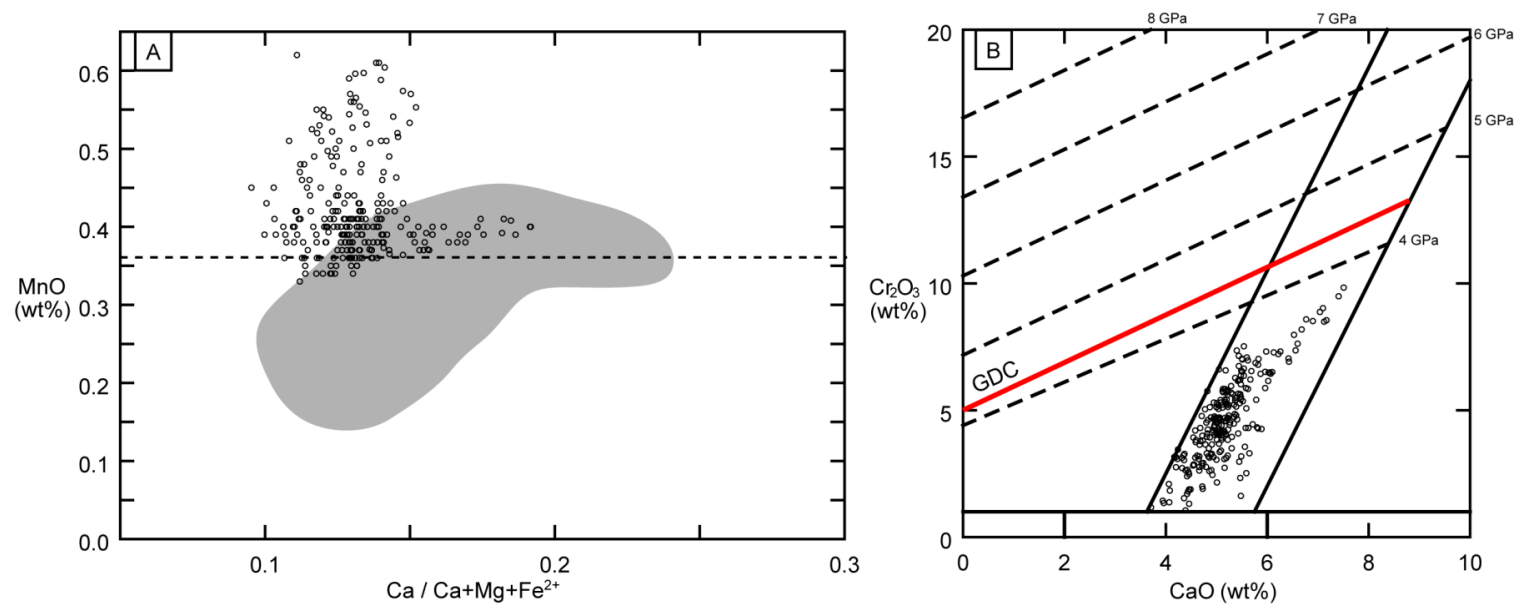

Figure 2. (a) $\mathrm{MnO}$ versus $\mathrm{Ca} / \mathrm{Ca}+\mathrm{Mg}+\mathrm{Fe}^{2+}$ for $\mathrm{G} 9$ from Victor. Based on $\mathrm{Mn}$-in-garnet thermometry, only garnets with $\mathrm{MnO}<0.36 \mathrm{wt} \%$ are expected to derive from depths within the diamond stability field (Grütter et al., 2004). Lherzolitic garnet inclusions in diamond (shaded field; database of Stachel and Harris, 2008) with $\mathrm{MnO}>0.36 \mathrm{wt} \%$ - typically showing elevated grossular contents in part associated with low Mg-numbers - highlight the restriction of this approach to a "normal" compositional range. (b) Ca-Cr plot for G9 from Victor. Cr-in-garnet barometry (Grütter et al., 2006) indicates P < 4 GPa, i.e. derivation from depth outside the diamond stability field. However, Cr-in-garnet yields only minimum pressures if the assemblage is not spinel saturated (Grütter et al., 2006), which is commonly the case for garnet lherzolites. Average Ca intercept values are $<4.3$, which indicates equilibration along a typical cratonic geotherm (Grütter et al., 2004).

garnets picked from mineral concentrate have garnets with $\mathrm{Na}_{2} \mathrm{O}>0.09 \mathrm{wt} \%$ (Figure 1). As bulk rock chemistry exerts a major control on $\mathrm{Na}_{2} \mathrm{O}$ in garnet, many high $\mathrm{Mg} \#$ garnets originating in the diamond stability field have low $\mathrm{Na}_{2} \mathrm{O}$ (Grütter and Quadling, 1999). Therefore, it is possible that more pyroxenite and eclogite xenoliths are from the diamond stability field, even if it is not indicated in their $\mathrm{Na}_{2} \mathrm{O}$ content. These results indicate that pyroxenite has the potential to be an important mantle source of diamonds in this region, as previously suggested for the AT56 kimberlite at Attawapiskat (Armstrong et al., 2004).

Lherzolite may also be a diamond source at Victor: Victor lherzolitic garnets have low Ca-intercept values (i.e., Cr$\mathrm{Ca}$ relations falling close to the division between harzburgitic and lherzolitic garnets; Figure 2b) suggesting derivation from SCLM falling on a typical cratonic geotherm (Grütter et al., 2004), which is indicative of the presence of a diamond stable SCLM in the Jurassic. MnO contents in $\sim 5 \%$ of lherzolitic garnets are $<0.36 \mathrm{wt} \%$ (Figure 2a), which is used as an approximate cutoff for diamond stable conditions by Grütter et al. (2004), based on Mn-in-garnet thermometery (Grütter et al., 1999). The thermometric expression of Grütter et al. (1999) does, however, ignore crystal chemical effects and, as a consequence, a number of lherzolitic garnet inclusions in diamond (by definition derived from the diamond stability field) with elevated grossular content and relatively low Mg-number fall above the $0.36 \mathrm{wt} \% \mathrm{MnO}$. Therefore, we are considering the proportion of $5 \%$ diamond stable lherzolitic garnets quoted above as a minimum value. The strongest indication for an elevated diamond potential of lherzolitic sources in the SCLM beneath Victor comes from a very high proportion of diamond stable $\mathrm{Cr}$ diopside in concentrate: after applying the geochemical filters of Grütter (2009) to extract clinopyroxenes that are (1.) garnet lherzolite derived and (2.) compositionally suitable for application of the Nimis and Taylor (2000) geothermobarometer, 35 of the remaining 41 (i.e., $81 \%$ ) Cr-diopside grains originate inside the diamond stability field.

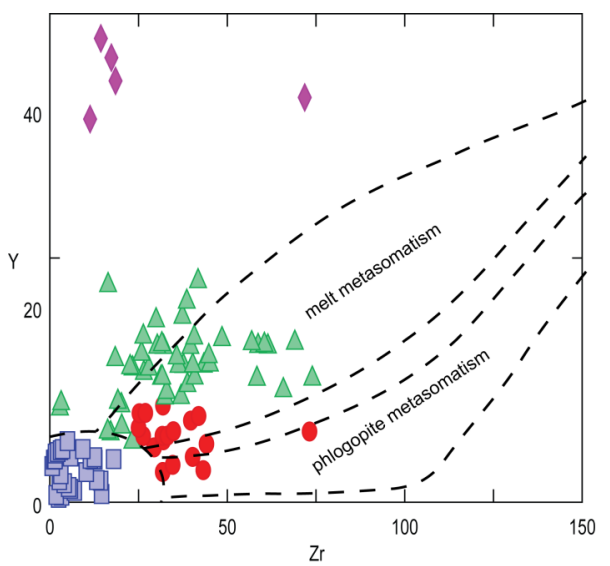

Figure 3. Y-Zr diagram from lherzolitic garnets documenting four different styles of metasomatism. Fields for melt and phlogopite (fluid) metasomatism from Griffin and Ryan (1995). Purple symbols - garnets re-enriched in $\mathrm{Y}$ but not in $\mathrm{Zr}$, through an agent with unfractionated HREE/MREE. Green symbols - garnets re-enriched in $\mathrm{Y}$ and $\mathrm{Zr}$ through melt-dominated metasomatism. Red symbols - garnets re-enriched in $\mathrm{Zr}$ more than Y through fluid-dominated metasomatism. Blue symbols "depleted" garnet. 


\section{$10^{\text {th }}$ International Kimberlite Conference, Bangalore - 2012}

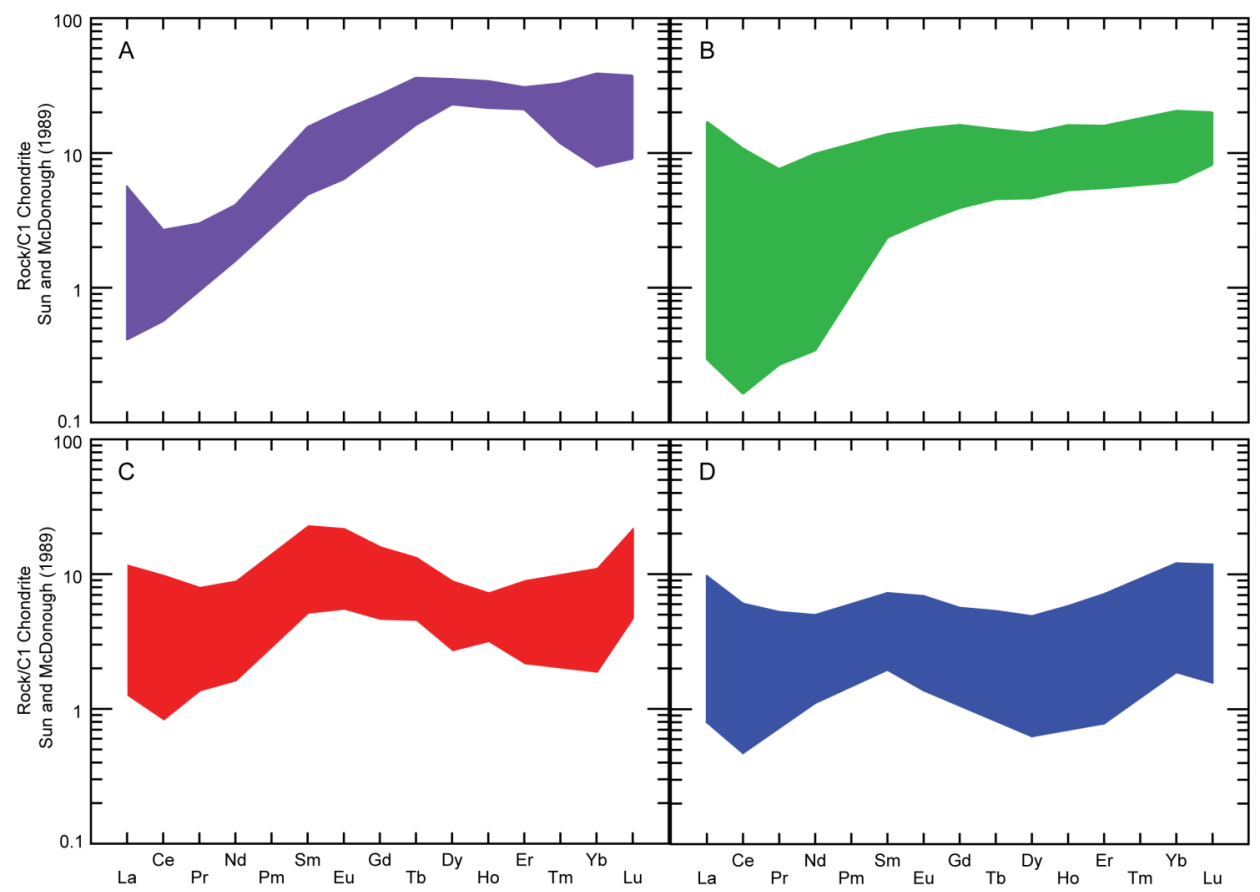

Figure 4. REE content for lherzolitic garnet normalised to C1Chondrite (Sun and McDonough, 1989). A. Garnet with positive slopes in MREE to HREE $_{N}$ suggest metasomatism by a HREE-enriched agent/melt. B. garnet from lherzolitic sources that have been melt metasomatised, with relatively flat slopes from $M_{R E E}$ to $\operatorname{HREE}_{\mathrm{N}}$. C. Garnet from sources affected by fluid-dominated metasomatism show enrichment in the LREE $\mathrm{N}_{\mathrm{N}}$ to $\mathrm{MREE}_{\mathrm{N}}$, resulting in complex sinusoidal pattern. D. Garnets that retain an originally depleted signature with a positive slope in the $\mathrm{HREE}_{\mathrm{N}}$ (reflecting melt extraction from a garnet bearing source) and some secondary LREE enrichment.

Lherzolitic garnets have both "depleted" and "enriched" REE compositions. Garnets that retain overall depleted signatures have complex sinusoidal $\mathrm{REE}_{\mathrm{N}}(\mathrm{N}=$ chondritenormalised) patterns, similar to harzburgitic and lherzolitic garnets from Kyle Lake (Scully et al., 2004). Despite minor LREE enrichment, these garnets have low $\mathrm{Y}$ and $\mathrm{Zr}$ contents $(<5 \mathrm{ppm}$ and $25 \mathrm{ppm}$, respectively), indicating that they were only affected by mild fluiddominated metasomatism (Figure 3 and Figure 4D). With these REE characteristics and the modest levels of $\mathrm{Y}-\mathrm{Zr}$ re-enrichment, the "depleted" lherzolitic garnets from Victor resemble garnets from diamondiferous lherzolite xenoliths from the Diavik Mine (Creighton et al., 2008).

Preservation of "depleted" garnet compositions below Victor suggests that the effect of the Midcontinent Rift may not have been that pervasive. "Enriched" garnets indicate both more intense fluid-dominated (increase in $\mathrm{Zr}$ content; LREE enrichment) and melt-dominated metasomatism (increase in both $\mathrm{Y}$ and $\mathrm{Zr}$ content; relatively flat $\mathrm{MREE}_{\mathrm{N}}$ to $\mathrm{HREE}_{\mathrm{N}}$ ) (Figure 3 and Figure 4B,C). Garnets that show enrichment in $\mathrm{Y}$ but not in $\mathrm{Zr}$ and a positive slope in the $\mathrm{MREE}_{\mathrm{N}}$ to $\mathrm{HREE}_{\mathrm{N}}$ are conside- red to have been enriched by an agent with fairly unfractionated HREE/MREE (Figure 3 and Figure 4A).

Our results indicate that whereas some diamond destruction may have occurred in relation to melt metasomatism in the SCLM below Attawapiskat, diamond-stable conditions were still prevalent in the lherzolitic SCLM during the Jurassic. The relationship of the melt metasomatic agent/s to the Midcontinent Rift will still be assessed. An additional source of diamonds below this area may be in the pyroxenitic and eclogitic SCLM.

\section{References}

Armstrong, K. A., Nowicki, T. E. \& Read, G. H., 2004. Kimberlite AT56: a mantle sample from the north central Superior craton, Canada Lithos, 77, 695-704.

Brey, G. P., Kohler, T. \& Nickel, K. G., 1990. Geothermobarometry in four-phase lherzolites: I. Experimental results from 10 to $60 \mathrm{kbar}$. Journal of Petrology, 31, 1313-1352.

Creighton, S., Stachel, T., McLean, H., Muehlenbachs, K., Simonetti, A., Eichenberg, D. \& Luth, R., 2008. Diamondiferous peridotitic microxenoliths from the Diavik Diamond Mine, NT. Contributions to Mineralogy and Petrology, 155, 541-554.

Griffin, W. L. \& Ryan, C. G., 1995. Trace elements in indicator minerals: area selection and target evaluation in diamond 


\section{$10^{\text {th }}$ International Kimberlite Conference, Bangalore - 2012}

exploration. Journal of Geochemical Exploration, 53, 311-337.

Grütter, H. S., 2009. Pyroxene xenocryst geotherms: Techniques and application. Lithos, 112S, 1167-1178.

Grütter, H. S. \& Quadling, K. E., 1999. Can sodium in garnet be used to monitor eclogitic diamond potential?. In: Proceedings of the 7th International Kimberlite Conference, Cape Town, 1998, (eds Gurney, J. J., Gurney, J. L., Pascoe, M. D. \& Richardson, S. H.), Vol. 1, pp. 314-320. Red Roof Design, Cape Town.

Grütter, H. S., Apter, D. B. \& Kong, J., 1999. Crust-Mantle Coupling: Evidence from Mantle-Derived Xenocrystic Garnets.. In: Proceedings of the 7th International Kimberlite Conference, Cape Town, 1998, (eds Gurney, J. J., Gurney, J. L., Pascoe, M. D. \& Richardson, S. H.), Vol. 1, pp. 307-313. Red Roof Design, Cape Town.

Grütter, H. S., Gurney, J. J., Menzies, A. H. \& Winter, F., 2004. An updated classification scheme for mantle-derived garnet, for use by diamond explorers. Lithos, 77 - Proceedings of the 8th International Kimberlite Conference, 841-857.

Grütter, H. S., Latti, D. \& Menzies, A. H., 2006. Cr-saturation arrays in concentrate garnet compositions from kimberlite and their use in mantle barometry. Journal of Petrology, 47, 801-820.

Heaman, L. M. \& Kjarsgaard, B. A., 2000. Timing of eastern North American kimberlite magmatism: continental extension of the Great Meteor hotspot track? Earth and Planetary Science Letters, 178, 253-268.

Kong, J. M., Boucher, D. R. \& Scott-Smith, B. H., 1999. Exploration and Geology of the Attwapiskat kimberlites, James Bay Lowland, Northern Ontario, Canada. Extended Abstracts of the 7th International Kimberlite Conference, Cape Town, pp. 446-448.

Krogh-Ravna, E., 2000. The garnet-clinopyroxene $\mathrm{Fe}^{2+}-\mathrm{Mg}$ geothermometer: an updated calibration. Journal of Metamorphic Geology, 18(2), 211-219.

McCammon, C., Griffin, W. L., Shee, S. R. \& O’Neill, H. S. C., 2001. Oxidation during metasomatism in ultramafic xenoliths from the Wesselton kimberlite, South Africa: implications for the survival of diamond. Contributions to Mineralogy and Petrology, 141, 287296.

McCandless, T. E. \& Gurney, J. J., 1989. Sodium in garnet and potassium in clinopyroxene: criteria for classifying mantle eclogites. Proceedings of the 4th International Kimberlite Conference, Perth, 1986, Geological Society of Australia Special Publication, 14(2), 827-832.

Nickel, K. G. \& Green, D. H., 1985. Empirical geothermobarometry for garnet peridotites and implications for the nature of the lithosphere, kimberlites and diamonds. Earth and Planetary Science Letters, 73, $158-170$.

Nimis, P. \& Taylor, W. R., 2000. Single clinopyroxene thermobarometry for garnet peridotites. Part I. Calibration and testing of a Cr-in-Cpx barometer and an enstatite-in-Cpx thermometer. Contributions to Mineralogy and Petrology, 139, $541-554$.

Sage, R. P., 1996. Kimberlites of the Lake Timiskaming structural zone. Ontario Geological Survey Open File Report, 5937.

Sage, R. P., 2000. Kimberlites of the Attawapiskat area, James Bay Lowlands, northern Ontario. Ontario Geological Survey, Open File Report, 6019(341), 341.

Scully, K. R., Canil, D. \& Schulze, D. J., 2004. The lithospheric mantle of the Archean Superior Province as imaged by garnet xenocryst geochemistry. Chemical Geology, 207, 189-221.

Stachel, T. \& Harris, J. W., 2008. The origin of cratonic diamonds constraints from mineral inclusions. Ore Geology Reviews, 34(1-2), $5-32$.

Stachel, T., Harris, J. W., Tappert, R. \& Brey, G. P., 2003. Peridotitic diamonds from the Slave and the Kaapvaal cratons - similarities and differences based on a preliminary data set. Lithos, 71, 489-503.

Sun, S.-S. \& McDonough, W. F., 1989. Chemical and isotopic systematics of oceanic basalts: implications for mantle compositions and processes.. In: Magmatism in the ocean basins, (eds Saunders, A. D. \& Norry, M. J.), pp. 313-345.
Geological Society, London.

van Schmus, W. R. \& Hinze, W. J., 1985. The Midcontinent Rift System. Annual Review of Earth and Planetary Sciences, 13, 345383.

White, W. S., 1972. Keweenawan flood basalts and continental rifting. Geological Association of America, Abstracts with Programs, 4, 732-734. 